\title{
Histochemical Demonstration of NADPH-Diaphorase Activity in the Pineal Organ of the Frog (Rana esculenta), But Not in the Pineal Organ of the Rat
}

\author{
Tetsuji SATo* \\ Department of Anatomy and Cytobiology, Justus Liebig-University, Giessen, Federal Republic of Germany
}

Received June 3, 1989

\begin{abstract}
Summary. Using the histochemical method for the demonstration of NADPH-diaphorase activity, the pineal organ of the frog and rat was investigated in serial sections. A positive NADPH-diaphorase activity was demonstrated in pinealocytes and nerve cells in the pineal organ of the frog, but not in the rat. An intense activity existed in the apical portion of the photosensitive pinealocytes of the frog. Large NADPH-diaphorase positive nerve cells (15-20 $\mu \mathrm{m}$ in diameter) were located within the parenchyma of the pineal organ in the frog. Large NADPH-positive nerve cells were more numerous in the rostral than in the caudal portion of the organ, but the intensely stained cells, counting 25-35 in number, showed almost equal distribution and number in the ventral and the dorsal aspect of the pineal organ. In their staining ability, NADPH-diaphorase positive pineal nerve cells resembled retinal amacrine cells.

The results in the pineal organ of the frog are discussed in light of previous morphological findings using the acetylcholinesterase reaction, and with electrophysiological results.
\end{abstract}

The presence of different types of neurons in the pineal organ of anurans has been demonstrated by supravital methylene blue staining and silver impregnation techniques (PAUL et al., 1971), and by the acetylcholinesterase (AChE) method (WAKE et al., 1974). However, the precise spatial and functional interrelationship of the cells is difficult to disentangle; unlike the organization of the retina, the wall of the pineal organ does not show a distinct pattern of layers.

The pineal organ of Rana ridibunda and Rana esculenta comprises two different types of nerve cells
- multipolar and pseudounipolar nerve cells - as shown by the AChE-method according to Karnovsky and Roots (WAKE et al., 1974), the former cells being closely connected to photosensitive pinealocytes, whereas the latter are scattered along the pineal tract, sending one process toward the brain. Therefore, it has been suggested that the former, multipolar cells are interneurons. A similar morphological differentiation of AChE-positive neurons has also been observed in the trout (KORF, 1974; EKSTRÖM and KORF, 1985), in the pike (FALCON, 1979), the European minnow (VIGH-TEICHMANN et al., 1982) and in several species of birds (UECK and KOBAYASHI, 1972; SATO and WAKE, 1983, 1984).

Recent investigations have achieved a selective demonstration of amacrine cells in the retina of several mammalian species using NADPH-diaphorase histochemistry (SANDELL, 1985; SAGAR, 1986; MÜLLER and PEICHL, 1987); in a previous paper I reported similar results in the frog and pigeon (SATO, 1990). The present paper aims at an initial investigation as to whether the pineal organ might contain NADPHdiaphorase positive cells. The study was carried out in a photosensitive pineal organ of the frog and in a merely secretory pineal organ of the rat.

\section{MATERIALS AND METHODS}

Ten adult Wistar rats (200-250 g) and 20 frogs, Rana esculenta, were investigated. The frogs were imported from Yugoslavia over the period from August till

\footnotetext{
*Fellow of the Alexander von Humboldt Foundation, Federal Republic Germany.

Present address: Department of Anatomy, Faculty of Medicine, Tokyo Medical and Dental University, Tokyo, Japan.
} 
Nevember. All animals were kept under natural light conditions. The animals were sacrificed between $9: 00$ and $12: 00$ a.m. as described below.

After opening the thorax under Ketavet anesthesia (i.m. $20 \mathrm{mg} / \mathrm{kg}$ body weight), the animals were perfused via the left ventricle or the aorta with $25-50 \mathrm{ml}$ of ice-cold saline followed by an aldehyde fixative solution. The perfusion was done with $100-250 \mathrm{ml}$ of an ice-cold mixture of $4 \%$ paraformaldehyde and $0.5 \%$ glutaraldehyde in $0.1 \mathrm{M}$ phosphate buffer $(\mathrm{pH} 7.4)$. After perfusion, the brain was quickly removed and left in $4 \%$ phosphate-buffered $(\mathrm{pH}$ 7.4) paraformaldehyde fixative for $2 \mathrm{~h}$ at $4^{\circ} \mathrm{C}$. The whole brains were stored overnight in $0.1 \mathrm{M}$ phosphate buffer $(\mathrm{pH} 7.4)$ containing $15 \%$ sucrose at $4^{\circ} \mathrm{C}$. Frontal, horizontal and sagittal sections ( $20 \mu \mathrm{m}$ thick) were serially cut on a cryostat (American Optical) and incubated for the demonstration of NADPH-diaphorase activity using the method of SCHERER-SingLER et al. (1983) (see SATO, 1990). From the serial sagittal sections of two frogs, the NADPH-diaphorase positive nerve cells were plotted at the light-microscopic level. Some in-toto preparations were also incubated for the demonstration of NADPH-diaphorase activity.

\section{RESULTS}

The NADPH-diaphorase method stains a distinct population of nerve cells in the brain-as is shown in the frog's striatum (Fig. 1). In the frog's pineal organ, NADPH-diaphorase positive nerve cells are visualized; additionally, an intense enzyme activity occurs in the apical protrusion of the photosensitive pinealocytes (Figs. 2-4), whereas the nuclei are unstained and the basal portion of the sensory cells seems to be faintly stained dependent on the thickness of the sections and the intensity of the staining. However, the pinealocytes are easy to distinguish from the visualized nerve cells: the latter are larger, spherical in shape and located at the basal of the parenchyma, while the former are smaller, elongated and contact the pineal lumen (Figs. 5-8).

Additional to the visualized photosensitive pinealocytes which contact the pineal lumen are demonstrated cells containing a spherical, NADPH-diaphorase positive region. These cells are located near the basal lamina (Figs. 3, 4).

The diaphorase-positive large nerve cells (15-20 $\mu \mathrm{m}$ in diameter) were counted in serial sections of two pineal organs (Fig. 9) at 25 and 35 in number. These cells predominate in the rostral part of the pineal organ, but a few cells are visible also in the caudal part. The stained nerve cells are seen similar in number in the ventral and the dorsal wall of the pineal organ. They are intramurally localized (Figs. 5-7): strong enzyme activity occurs in the cytoplasm of the perikarya, but the processes of the nerve cells are only faintly stained in comparison to the strong results in nerve cells of the brain (Fig. 1) and in some types of amacrine cells of the retina (SATO, 1990). In addition to the large intramural nerve cells, some smaller nerve cells can be visualized in the dorsal wall (Fig. 8); the total number of the latter cell type is difficult to count because of the diminished intensity of the staining and the extremely thin cytoplasmic layer surrounding the unstained nucleus.

Contradictory to the staining of photosensitive pinealocytes in the frog's pineal organ is the result in the rat's pineal organ. Here, no recognizable $\mathrm{NADPH}$-diaphorase activity could be recognized in the secretory pinealocytes of the rat. The visualization of distinct neurons in adjacent brain areas (Fig. 10) supports the view that the pinealocytes of rats are NADPH-diaphorase negative.

\section{DISCUSSION}

The NADPH-diaphorase-method provided a demonstration of pinealocytes and nerve cells in the pineal organ of Rana esculenta. The reaction product of the diaphorase activity is localized in the cytosol, according to an ultrastructural study by VINCENT and JOHANSSON (1983). Neurohistological studies using methylene blue, Bodian or Golgi techniques in the pineal organ (STUDNIČKA, 1905; HOLMGREN, 1918, 1919; OKSCHE, 1955; PAUL et al., 1971) visualized only part of the nervous apparatus. The best results to date were obtained by using the AChE-reaction (WAKE et al., 1974). Two different types of AChEreactive nerve cells have been distinguished: multipolar cells and smaller pseudounipolar cells. The former cells are localized within the parenchyma, while the perikarya of the latter often protrude into the perivascular connective tissue. Concerning the function of these two main types of nerve cells, it has been suggested from the results of WAKE et al. (1974) that the pseudounipolar cells give rise to the pineal tract, while the multipolar elements have been interpreted as interneurons. From their size and localization, we compare the large NADPH-diaphorase positive cells with the multipolar cells shown with the AChE-method. Moreover, from the intimate spatial relationship between the photosensitive pinealocytes and the large NADPH-diaphorase positive neurons 

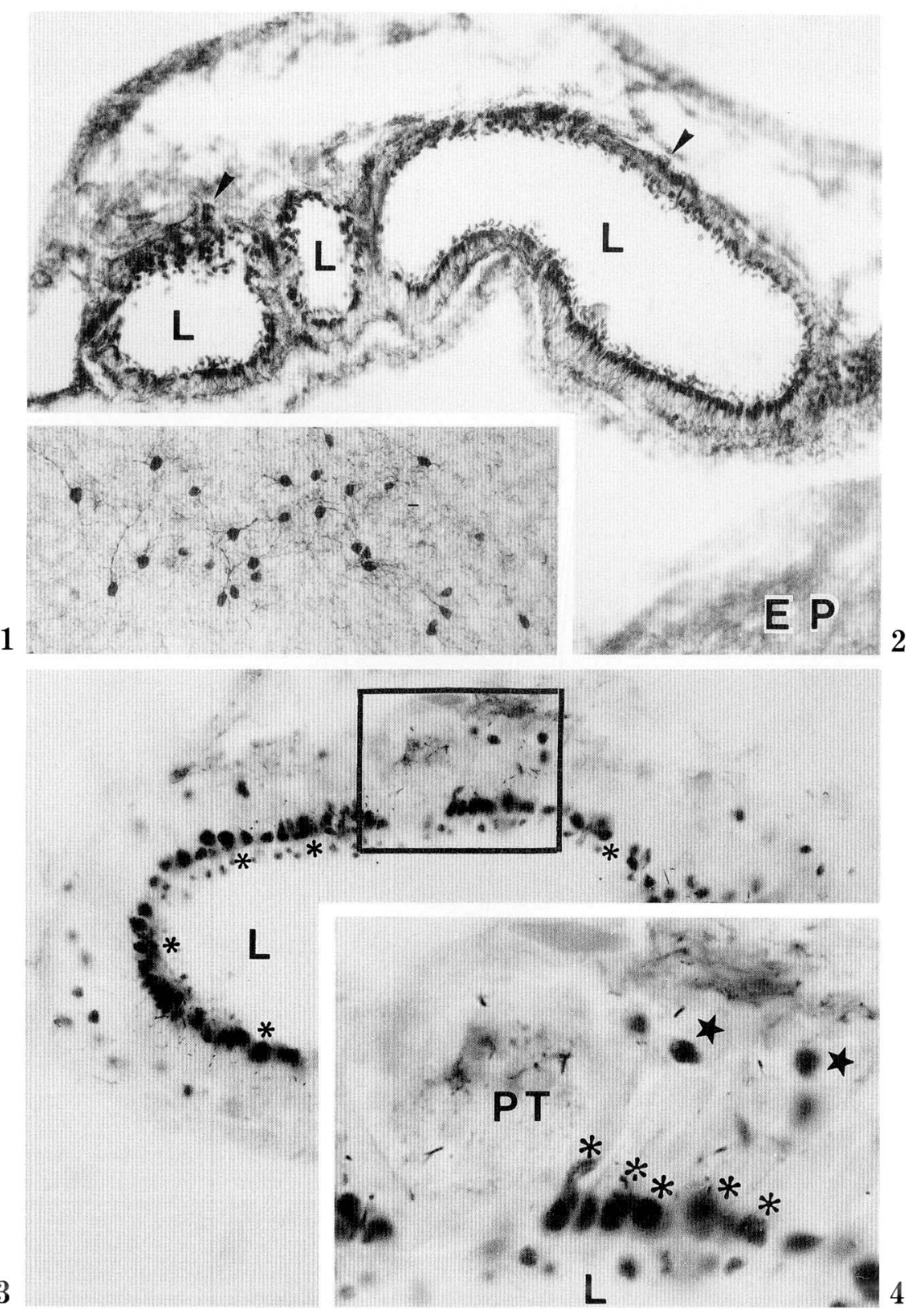

Figs. 1-4. Rana esculenta, NADPH-diaphorase method. Fig. 1. Sagittal section of an area from the torus semicircularis of the frog brain. A distinct population of neurons demonstrated in a Golgi-like image: perikarya, dendritic trees, and axons are stained. $\times 130$. Fig. 2. Mid-sagittal section of the frog pineal organ. Adjacent to the pineal lumen $(L)$, the apical portion of the photosensitive pinealocytes is intensely stained. Arrowheads indicate positive neurons. $E P$ epithalamus. $\times 210$. Fig. 3. Frontal section of the pineal organ. Innersegments of photosensitive pinealocytes (asterisks) are initially stained after a short incubation time $(60 \mathrm{~min}) . L$ pineal lumen. $\times 560$. Fig. 4 . A higher powered view of an area marked by the rectangle in Fig. 3. Beside the photosensitive pinealocytes (asterisks) adjacent to the pineal lumen $(L)$, cells (solid stars) are stained containing a spherical, NADPH-diaphorase positive product; these cells are located near the basal lamina; they obviously have no contact with the pineal lumen. $P T$ pineal tract. $\times 1,150$ 

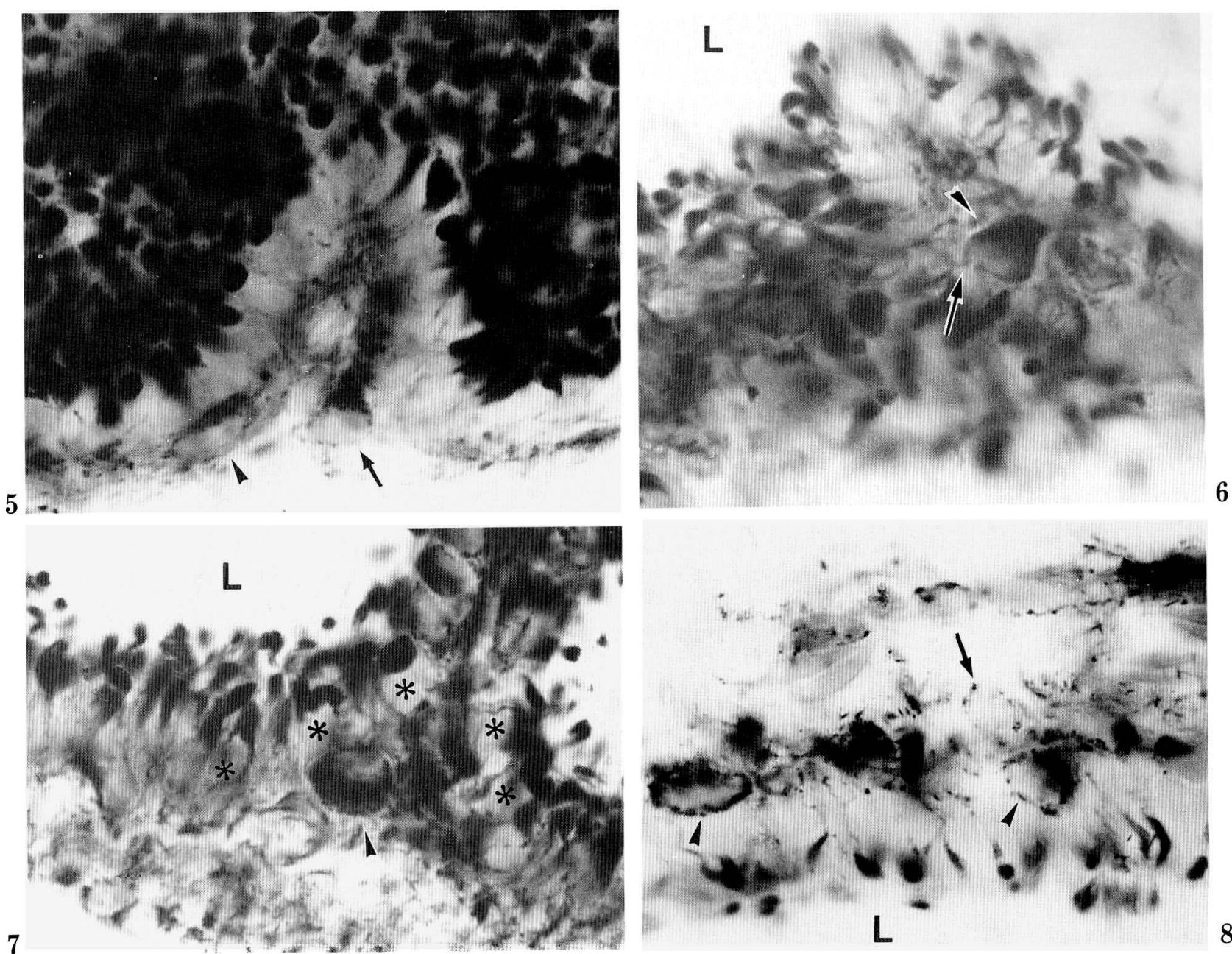

6

Figs. 5-8. Rana esculenta. NADPH-diaphorase method. Fig. 5. Border of part of the lateral side of the pineal organ, in-toto preparation. A large intensely stained nerve cell (arrowhead) is intramurally localized, while a smaller nerve cell (arrow) can be extramurally visualized. Within the parenchyma lie many intensely stained innersegments of photosensitive pinealocytes. $\times 680$. Fig. 6. A horizontal section of the pineal organ showing a multipolar cell (arrowhead) within the parenchyma. Arrow indicates a process of the nerve cell. $L$ pineal lumen. $\times 960$. Fig. 7. A sagittal section of the pineal organ showing a large nerve cell (arrowhead) in the parenchyma. The cytoplasm but not the nucleus is stained in both the neuron and the photosensitive pinealocyte (asterisks). $L$ pineal lumen. $\times 960$. Fig. 8. A sagittal section of the dorso-caudal portion of the pineal organ. Large, intensely stained nerve cells (arrowheads) lie within the parenchyma, and a weakly labeled nerve cell (arrow) protrudes into the perivascular connective tissue. $\times 1,070$

(SATO and UECK, 1989; UECK et al., 1989), and, on the other hand, between the multipolar cells and pseudounipolar nerve cells (WAKE et al., 1974), it has been emphasized that the multipolar cells of the frog pineal organ might be interneurons. The NADPH-diaphorase method selectively stains types of amacrine cells in the inner nuclear layer of the frog's retina (SATO, 1990). Multipolar nerve cells in the pineal organ of the frog, Rana esculenta, are similar to retinal amacrine cells in respect to their NADPH-diaphorase- and AChEactivity.

Cells characterized by a spherical, NADPHdiaphorase positive region in their cytoplasm and by their location near the basal lamina (Figs. 3, 4) are obviously without contact with the pineal lumen; they are assumed to be modified pinealocytes because of the similarity of their stained area with that of the inner segment of the photosensitive cell. Modified 


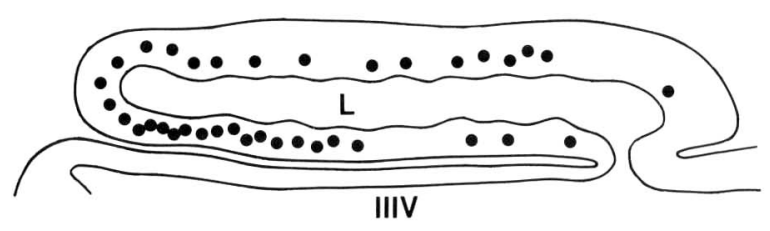

Fig. 9. Drawing from serial sagittal sections showing the distribution of thirty-five NADPH-positive neurons (black dots) in the pineal organ of the frog. NADPHpositive cells are distributed more densely in the rostral than in the caudal portion of the organ. $L$ pineal lumen, IIIV third ventricle.

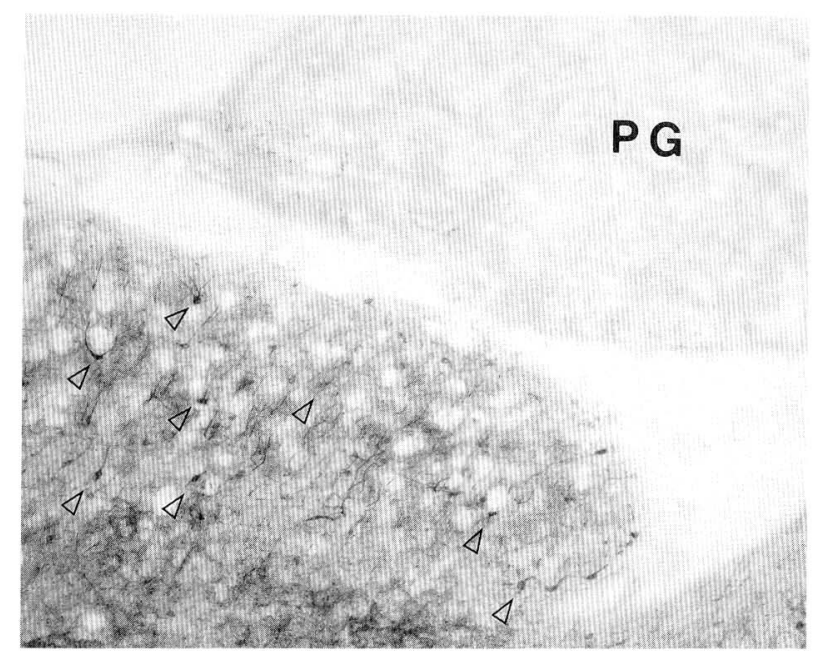

Fig. 10. A mid-sagittal section of the rat brain. $P G$ pineal gland. A sparse population of NADPH-diaphorase positive neurons (open arrowheads) is detected in the forebrain cortex, whereas no NADPH-diaphorase activity is observed in the pineal gland. $\times 100$

pinealocytes have been described in other lower vertebrates, i.e., the lamprey (MEINIEL, 1981).

The direct photosensitivity of the pineal complex of Anura is clearly demonstrated by electrophysiological studies. Direct illumination of the frontal organ is followed by chromatic and achromatic responses, whereas the pineal organ proper usually responds achromatically (DODT and HEERD, 1962; MoRitA, 1965; DODT et al., 1971; DoDT, 1973). A detailed description of morphological characteristics of the frontal organ shown by the NADPH-diaphorase method is in preparation.

Conventional synapses have been observed beside the ribbon synapses in the pineal organ of the frog. Their functional significance is obscure, but it has been suggested that they may be linked to interneu- rons (BAYRHUBER, 1972; KORF, 1976). Therefore, it is relevant to investigate the synapse formation using the NADPH-diaphorase method at the ultrastructural level.

Distinct populations of neurons have been confirmed with the NADPH-diaphorase histochemistry in the rat brain (Fig. 10), similar to the previous observations by SCHERER-SINGLER et al. (1983), VINCENT et al. (1983), and VINCENT and JOHANSSON (1983). However, no NADPH-diaphorase activity coulld be recognized in the pineal organ. Considering that the pineal organ of the rat is free of neuronal perikarya (Ariëns KAPPERS, 1960, 1965), the absence of diaphorase-activity should be ascribed to the feature of pinealocytes. This difference in staining ability of photosensitive pinealocytes and retinal photoreceptors on one hand and secretory mammalian pinealocytes on the other hand is interesting in respect to the general discussion of retinal and pineal relationships (for literature see O'BRIEN and KLEIN, 1986).

Acknowledgement. This work was supported by grants from the Alexander von Humboldt Foundation. The author is indebted to Professor M. UECK for his patient support and valuable discussions and thanks Mrs. A. $\mathrm{HACH}$ for her efficient technical assistance.

\section{REFERENCES}

Bayrhuber, H.: Über die Synapsenformen und das Vorkommen von Acetylcholinesterase in der Epiphysis von Bombina variegata (L.), (Anura). Z. Zellforsch. 126: 278-296 (1972).

DoDT, E.: The parietal eye (pineal and parietal organs) of lower vertebrates. In: (ed. by) R. JUNG: Handbook of sensory physiology, VII/3B. Springer, Berlin-HeiderbergNew York, 1973 (p. 113-140).

DoDT, E. and E. HEERD: Mode of action of pineal nerve fibers in frogs. J. Neurophysiol. 25: 405-429 (1962).

DodT, E., M. UeCK and A. OKsche: Relations of structure and function: The pineal organ of lower vertebrates. In: (ed. by) V. KrutA: J. Purkyne Centenary Symposium, Prag 1969. Universita J. E. Purkyne, Brno, 1971 (p. 253-278).

Eкström, P. and H.-W. KoRf: Pineal neurons projecting to the brain of the rainbow trout, Salmo gairdneri Richardson (Teleostei). In vitro retrograde filling with horseradish peroxidase. Cell Tiss. Res. 240: 693-700 (1985).

Falcon, J.: Unusual distribution of neurons in the pike pineal organ. In: (ed. by) Ariëns KAPpers and P. PEvet: The pineal gland of vertebrates including man (Progr. Brain Res. Vol. 52). Elsevier, Amsterdam, 1979 (p. 89-91). 
Holmgren, N.: Zur Kenntnis der Parietalorgane von Rana temporaria. Ark. Zool. 11 (24): 1-13 (1918, 1919).

KAPPERS, J. A.: The development of topographical relations and innervation of the epiphysis cerebri in the albino rat. Z. Zellforsch. 52: 163-215 (1960).

-: Survey of the innervation of the epiphysis cerebri and the accessory pineal organs of vertebrates. In: (ed. by) Ariëns KAPPERS and J. P. ScHADE: Structure and function of the epiphysis cerebri (Progr. Brain Res. Vol. 10), Elsevier, Amsterdam, 1965 (p. 87-153).

KoRF, H.-W.: Acetylcholinesterase-positive neurons in the pineal and parapineal organs of the rainbow trout, Salmo gairdneri (with special reference to the pineal tract). Cell Tiss. Res. 155: 475-489 (1974).

- : Histological, histochemical and electron microscopical studies on the nervous apparatus of the pineal organ in the tiger salamander, Ambystoma tigrinum. Cell Tiss. Res. 174: 475-497 (1976).

Meiniel, A.: New aspects of the phylogenetic evolution of sensory cell lines in the vertebrate pineal complex. In: (ed. by) A. OKSche and P. Pevet: The Pineal Organ: Photobiology-Biochronometry-Endocrinology. Elsevier, Amsterdam, 1981 (p. 27-48).

MoRita, Y.: Extra- und intracellulaere Ableitungen einzelner Elemente des lichtempfindlichen Zwischenhirns anurer Amphibien. Pfluegers Arch. ges. Physiol. 286: 97-108 (1965).

Müller, F. and L. Peichl: Histochemical demonstration of an amacrine cell population: NADPH diaphorase staining in different mammalian retinae (Abstract). In: (ed. by) N. ELSNER and O. CREuTZFELDT: Proc. 15th Goettingen Neurobiology Conference. George Thieme Verlag, Stuttgart-New York, 1987 (p. 314).

O'Brien, P. J. and D. C. KLein: Pineal and retinal relationships. Academic Press, Orlando, 1986.

OKsche, A.: Untersuchungen über die Nervenzellen und Nervenverbindungen des Stirnorgans, der Epiphysis und des Subcommissuralorgans bei anuren Amphibien. Morphol. Jahrb. 95: 393-425 (1955).

Paul, E., H. G. Hartwig and A. OKsche: Neurone und zentralnervöse Verbindungen des Pinealorgans der Anuren. Z. Zellforsch. 112: 466-493 (1971).

Sagar, S. M.: NADPH diaphorase histochemistry in the rabbit retina. Brain Res. 373: 153-158 (1986).

SANDELL, J. H.: NADPH diaphorase cells in the mammalian inner retina. J. Comp. Neurol. 238: 466-472 (1985).

SAT0, T.: NADPH-diaphorase positive amacrine cells in the retina of the frog (Rana esculenta) and pigeon (Columbia livia). Arch. Histol. Cytol. 53: 63-69 (1990).

SATo, T. and M. UECK: NADPH diaphorase-positive cells in the retina and pineal organ of frogs (Abstract). Acta Anat. Nippon. 64: 420 (1989).

SAT0, T. and K. WAKE: Innervation of the avian pineal organ: A comparative study. Cell Tiss. Res. 233: 237264 (1983).
- Regressive post-hatching development of acetylcholinesterase-positive neurons in the pineal organs of Coturnix coturnix japonica and Gallus gallus. Cell Tiss. Res. 237: 269-275 (1984).

Scherer-Singler, U., S. R. Vincent, H. Kimura and E. G. MCGEER: Demonstration of a unique population of neurons with NADPH diaphorase histochemistry. J. Neurosci. Methods 9: 229-234 (1983).

STUdničKA, F. K.: Die Parietalorgane. In: (ed. by) A. OPEL: Lehrbuch der vergleichenden mikroskopischen Anatomie der Wirbeltiere, Vol. 5. Jena, Fischer, 1905 (p. 1-254).

UecK, M. and H. KobaYASHI: Vergleichende Untersuchungen über acetylcholinesterasehaltige Neurone im Pinealorgan der Vögel. Z. Zellforsch. 129: 140-160 (1972).

UECK, M., T. SATO, S. OHBA, K. W AKE and H. KobaYASH: The neural organization of the pineal complex in the frog: Stratification and regional differences. Arch. Histol. Cytol. 52, Suppl.: 459-467 (1989).

Vigh-TeichmanN, I., H.-W. Korf, A. OKsche and B. VIGH: Opsin-immunoreactive outer segments and acetylcholinesterase-positive neurons in the pineal complex of Phoxinus phoxinus (Teleostei, Cyprinidae). Cell Tiss. Res. 227: 351-369 (1982).

Vincent, S. R. and O. Johansson: Striatal neurons containing both somatostatin- and avian pancreatic polyeptide (APP)-like immunoreactivities and NADPHdiaphorase activity: A light and electron microscopic study. J. Comp. Neurol. 217: 264-270 (1983).

Vincent, S. R., O. Johansson, T. Hökfelt, L. Skirboll, R. P. Elde, L. Terenius, J. Kimmel and M. Gold STEIN: NADPH-diaphorase: A selective histochemical marker for striatal neurons containing both somatostatin- and pancreatic polypeptide (APP)-like immunoreactivities. J. Comp. Neurol. 217: 252-263 (1983).

W AKE, K., M. UECK and A. OKsCHE: Acetylcholinesterase-containing nerve cells in the pineal complex and subcommissural area of the frogs, Rana ridibunda and Rana esculenta. Cell Tiss. Res. 154: 423-442 (1974).
Dr. Tetsuji SATO
Department of Anatomy
Faculty of Medicine
Tokyo Medical and Dental University
Yushima, Bunkyo-ku
113 Japan
佐 藤 哲二
113 東京都文京区湯島 1-5-45
東京医科歯科大学医学部
第一解剖学教室 